Artigo original

Hegemonia - Revista Eletrônica de Relações Internacionais do Centro Universitário Unieuro

ISSN: $1809-1261$

UNIEURO, Brasília, número 17, 2016, pp. 174-204.

Recebido em: 7/9/2015

Avaliado em: 17/10/2015

Aprovado em: 21/11/2015

\title{
O conceito de heteronomia para a compreensão das violações dos Direitos Humanos durante repressão à luta armada no Brasil
}

Hugo Studart ${ }^{1}$

Resumo: Uma das questões que mais intrigam nos estudos sobre o regime militar instaurado no Brasil em 1964, especialmente o aparelho de repressão à luta armada, é tentar compreender por qual razão as Forças Armadas aceitaram as violações sistemáticas aos Direitos Humanos como práxis do Estado durante a repressão às organizações da luta armada nas décadas de 1960-70. Os militares, por tradição, forjados nos mais rígidos valores cristãos e no ideário positivista, foram protagonistas de algumas das mais relevantes páginas da nossa História, da Proclamação da República à restauração da democracia em 1945. Contudo, com o regime militar de 1964, passaram a prender opositores de forma arbitrária e disseminada. A fazer uso da tortura em interrogatórios nos porões da repressão política. A executar prisioneiros na calada da noite. A desaparecer com seus restos mortais. Instauraram, enfim, a barbárie como modus operandi da repressão do Estado, em nome de uma suposta Segurança Nacional. Este ensaio se divide em quatro partes: 1) Historiciza a participação dos militares na política; 2) Explica a formação do Sistema de Inteligência e da Comunidade de Segurança e de Informações; 3) Expõe o modus operandi da repressão; 4) Por fim, tece reflexões sobre o conceito de heteronomia, apresentado inicialmente por Hannah Arendt e, mais tarde, aprofundado pelo filósofo Cornelius Castoriadis. A heteronomia deve ser entendida como a condição de pessoa ou de grupo que receba de um elemento

Doutor em História, professor na Universidade Católica de Brasília e pesquisador do Centro de Estudos da Paz e dos Direitos Humanos da Universidade de Brasília. 
Artigo original

Hegemonia - Revista Eletrônica de Relações Internacionais do Centro Universitário Unieuro

ISSN: $1809-1261$

UNIEURO, Brasília, número 17, 2016, pp. 174-204.

que lhe é exterior, ou de um princípio estranho à razão, a lei a que se deve submeter.

Palavras-chave: Regime Militar. Luta Armada. Repressão. Valores Morais. Heteronomia.

Abstract: One of the most intriguing questions in the studies of the military regime in Brazil in 1964, especially the apparatus of repression to armed struggle, is trying to understand why the military forces had accepted the systematic human rights violations as state praxis during the crackdown on the organizations of armed struggle in the 1960s and 1970s. The military was traditionally forged in the strictest Christian values and positivist ideas. However they were protagonists of some of the most important moments in the history of Brazil, like that the Proclamation of the Republic and the restoration of democracy in 1945. In the military regime of 1964, they had passed to arrest opponents arbitrarily and disseminated. They also make use of torture in interrogations in the basements of political repression, executing prisoners and disappearing with his remains. They installed the barbarism as the modus operandi of state repression in the name of a supposed National Security. This essay is divided into four parts: 1 ) historicizing the participation of the military in politics; 2) Explain the formation of the Intelligence System and the Community Security and Information; 3) Expose the modus operandi of repression; 4) Finally, weave reflections on the concept of heteronomy, that is initially presented by Hannah Arendt and later deepened by the philosopher Cornelius Castoriadis. The heteronomy should be understood as the condition of the person or group receiving an element that is external, or a strange principle to reason, the law to which the people must submit themselves.

Palavras-chave: Military regime. Armed struggle. Crackdown. Moral Values. Heteronomy.

Introdução: Partido Fardado 
Artigo original

Hegemonia - Revista Eletrônica de Relações Internacionais do Centro Universitário Unieuro

ISSN: $1809-1261$

UNIEURO, Brasília, número 17, 2016, pp. 174-204.

Foi Oliveira Viana quem definiu como "um poderoso fetiche de dragonas e punhos estrelados" o sentimento que as elites políticas brasileiras costumavam nutrir, desde o Império, pelos militares. "Eu os identifico a todos", disse, de certa feita, o marechal Castelo Branco, primeiro presidente da República do regime militar (1964-1966). "E são muitos deles, os mesmos que, desde 1930, como vivandeiras alvoroçadas, vêm aos bivaques bulir com os granadeiros e provocar extravagâncias do poder militar" ${ }^{\prime 2}$. Oliveiros Ferreira ${ }^{3}$, em Vida e Morte do Partido Fardado ${ }^{4}$, ressalta que sempre houve uma relação conturbada, de amor e ódio, entre civis e militares brasileiros:

\section{Houve momentos em que, no mundo político e civil, as Forças Armadas foram consideradas como o inimigo do Poder Constitucional; outros, em que}

Castelo disse a frase em agosto de 1964, no auditório da Escola de Comando e Estado Maior do Exército. $\mathrm{Na}$ verdade, queixava-se dos civis que acusavam seu governo de militarista. A frase foi incorporada ao imaginário político brasileiro.

Professor-titular de Ciência Política da Universidade de São Paulo e um dos mais reconhecidos especialistas em questões militares em atividade no país. Autor, entre outros trabalhos, de Os 45 Cavalheiros Húngaros - Uma leitura dos Cadernos de Gramsci. Brasília: Editora Universidade de Brasília; São Paulo: Hucitec, 1986. 


\section{Artigo original}

Hegemonia - Revista Eletrônica de Relações Internacionais do Centro Universitário Unieuro

ISSN: $1809-1261$

UNIEURO, Brasília, número 17, 2016, pp. 174-204.

os próceres do mundo civil bateram às portas dos quartéis para pedir aos militares que interviessem na política para ajudá-los a manter o status quo ou, então, para que facilitassem mudanças na estrutura política, social ou econômica do país, mudanças essas que eles, civis, não tinham, digamos, certeza de poder realizar sozinhos por meio do mero jogo político 5 .

Do lado dos militares, a aliança nunca se fez sem reservas mentais, pois não deixavam de perceber na ação dos próceres civis o desejo de servir-se das Forças Armadas para, depois, descartá-las como limão espremido, quando não acabar com elas enquanto organização. Essa relação conturbada, em que a ideia que um grupo fazia do outro sempre impediu que o lacre sobre o qual se apunha o selo da aliança fosse de boa qualidade, não foi motivo para refrear o impulso dos civis de baterem às portas dos quartéis nem, muito menos, o seu aspecto negativo bastou para que, em determinadas circunstâncias, os militares deixassem de aceitar a tarefa que the era pedida realizar ${ }^{6}$.

Op.Cit., pág. 09. 
Artigo original

Hegemonia - Revista Eletrônica de Relações Internacionais do Centro Universitário Unieuro

ISSN: $1809-1261$

UNIEURO, Brasília, número 17, 2016, pp. 174-204.

Em Os Militares na Política ${ }^{7}$, Alfred Stepan lembra que, historicamente, os "civis que formam as camadas politicamente importantes" da sociedade brasileira "sempre tentaram servir-se dos militares para atingir seus próprios objetivos políticos". Em seus estudos sobre o tema, Stepan trabalha com a hipótese da existência daquilo que ele batizou de "padrão moderador" das relações entre civis e militares. Segundo ele, haveria um padrão repetitivo nas intervenções militares verificadas na história brasileira e de toda a América Latina, na qual diferentes grupos políticos tentam cooptá-los para atingir seus próprios objetivos de poder. Seria esse o "padrão moderador" dos militares. Stepan explica:

Um aspecto fundamental do relacionamento civilmilitar é a tensão potencial que se manifesta diante de uma dupla necessidade dos governantes políticos civis: de um lado, manter uma força armada como instrumento da política e da ordem interna e, de outro, garantir que o poder militar não usurpe o poder político ${ }^{8}$.

As exigências políticas são elevadas, mas a capacidade política de convertê-la em resultados

1975.

Alfred Stepan. Os Militares na Política. Trad. Ítalo Tronca. Rio de Janeiro: Artenova, $1^{\text {a }}$ ed.,

Op. Cit. Pág. 46. 


\section{Artigo original}

Hegemonia - Revista Eletrônica de Relações Internacionais do Centro Universitário Unieuro

ISSN: $1809-1261$

UNIEURO, Brasília, número 17, 2016, pp. 174-204.

efetivos é pequena. A sociedade é pretoriana ${ }^{9}$, no sentido de que todas as instituições - a igreja, o trabalho, os estudantes - são altamente politizados. Ao mesmo tempo, porém, as instituições políticas são fracas. Nesse tipo de sociedade, os militares também são politizados e todos os grupos tentam cooptá-los para aumentar sua força política"10.

Também para Octavio Ianni, todo o movimento que pratica a Realpolitik inclui forças militares em seus esquemas:

É por essas razões que as Forças Armadas se tornaram alvo das atenções, insinuações e manobras de todos os partidos ambiciosos. Por isso é que todos louvam o 'espírito democrático' do Exército nacional ${ }^{11}$.

O conceito das sociedades pretorianas é de Max Weber.

Idem, pág. 49. 1965.

Octavio Ianni. Política e revolução social no Brasil". Rio de Janeiro : Civilização Brasileira, 
Hegemonia - Revista Eletrônica de Relações Internacionais do Centro Universitário Unieuro

ISSN: $1809-1261$

UNIEURO, Brasília, número 17, 2016, pp. 174-204.

Em referência a Thomas Hobbes, autor do clássico O Leviatã, Oliveiros Ferreira chama de "a longa noite hobbesiana" o período no qual as Forças Armadas protagonizaram forte influência na condução do processo político brasileiro - uma noite que durou um século e meio, com início em 1821, quando a tropa do Rio de Janeiro obriga o príncipe regente Pedro de Alcântara a substituir o ministro da Guerra $^{12}$, e que se prolongaria até 1985 , quando o último general no poder ${ }^{13}$ deixou o Palácio do Planalto pela porta dos fundos ${ }^{14}$.

Nesse século e meio, foram pelo menos 15 as intervenções políticas dos militares em momentos decisivos da história brasileira.

No dia 5 de abril de 1821 a tropa paga (ainda não eram forças regulares) sublevou-se, exigindo a demissão do ministro da Guerra, Conde dos Arcos. Acuado, sem possibilidade de chamar reforços, o príncipe cedeu, nomeando para o cargo o desembargador Álvaro Dinis, indicado pelo comandante da tropa. In: Francisco Adolfo de Varnhagem. História da Independência do Brasil. Rio de Janeiro: Imprensa Nacional, 1940. Apud: Oliveiro Ferreira, Op. Cit.

O presidente João Baptista Figueiredo recusou-se a passar a faixa presidencial a seu sucessor civil, José Sarney, preferindo deixar o palácio escondido, pela garagem dos fundos.

Oliveiros Ferreira, contudo, apresenta o ano de 1969 como o marco do fim da "longa noite hobbesiana". Isso porque, naquele ano, os ministros militares criaram uma série de regras internas de promoção e aposentadoria que, na prática, acabou com a possibilidade de surgirem lideranças carismáticas dentro das Forças Armadas. A partir daí, segundo Oliveiros, as intervenções políticas armadas ficariam inviáveis. Apesar dessa demarcação do autor, minha opção foi por fixar o fim da "noite hobbesiana" - expressão que tomei empestada - coincidindo com a saída do último general do poder. 
Artigo original

Hegemonia - Revista Eletrônica de Relações Internacionais do Centro Universitário Unieuro

ISSN: $1809-1261$

UNIEURO, Brasília, número 17, 2016, pp. 174-204.

Em alguns deles, como a renúncia de Pedro I, em 1831, e a Revolução de 1930, foram os militares meros coadjuvantes, levados à ação por civis que apareceram nos bivaques a fim de bulir com os granadeiros, como diria Castelo Branco. Outros episódios, como a proclamação da República, em 1889, e a imposição do Ato Institucional n05, o AI-5, em dezembro de $1968^{15}$, foram grupos militares que teriam tomado a iniciativa, na condição de atores principais do processo político. Há ainda aqueles movimentos que ganharam as ruas a partir de uma aliança entre civis e militares, como a instituição do Estado Novo, em 1937, a deposição de Getúlio Vargas, em 1945.

Essa uma relação ciclotímica e incestuosa entre civis e militares já perdurava 143 anos quando, a 31 de março de 1964, um fato relevante ocorreria no Brasil, provocando feridas profundas em nossa história - até hoje não cicatrizadas.

\section{O Monstro-Onividente}

Uma das obras mais conhecidas do regime militar instaurado em 1964 seria a criação de um sistema de informações e de segurança para o Estado, poderoso como o Leviatã, complexo, gigantesco, original, invisível, um sistema que tinha por função primordial vigiar com seus olhos, como os mil olhos de Argos, as entranhas do tecido social para ajudar os militares a governar com mãos de ferro - onividentes, mas invisíveis. Em seus estudos sobre o

O Ato Institucional $n^{\circ}$ 5, de 13 de dezembro de 1968, instaurou um regime de exceção no país, suspendendo uma série de garantias e direitos, como o habeas corpus, em nome da segurança nacional e da necessidade do "combate ao terrorismo". 
Artigo original

Hegemonia - Revista Eletrônica de Relações Internacionais do Centro Universitário Unieuro

ISSN: $1809-1261$

UNIEURO, Brasília, número 17, 2016, pp. 174-204.

fenômeno da vigilância como instrumento de poder, Michel Foucault explica:

Seu funcionamento é de uma rede de relações de alto a baixo, mas também de um certo modo de baixo para cima e lateralmente; essa rede 'sustenta' o conjunto, e o perpassa de efeitos de poder que se apoiam uns sobre os outros; fiscais perpetuamente fiscalizados. O poder na vigilância hierarquizada das disciplinas não se detém como uma coisa, não se transfere como uma propriedade; funciona como uma máquina. ${ }^{16}$

Carlos Fico ${ }^{17}$ apresenta uma análise original sobre como funcionava essa máquina de vigiar - e talvez de punir. Os militares criaram, em verdade, duas diferentes máquinas de vigilância e de controle social. Uma foi chamada de Comunidade de Informações; essa só vigiava. A outra era a Comunidade de Segurança; essa vigiava e punia. Juntas, as duas máquinas formavam o Sistema de Informações e de Segurança do regime militar. Fico lembra que o imaginário brasileiro acabou consolidando uma impressão distorcida do verdadeiro papel e dos integrantes dessa comunidade, misturando as atividades de inteligência com as de repressão política, espionagem, tortura e execuções, sob a égide dos folclóricos

Michel Foucault. Vigiar e Punir. 18ª ed., Petrópolis: Ed. Vozes, 1987, pág. 148.

Carlos Fico. Além do Golpe - Versões e controvérsias sobre 1964 e a Ditadura Militar. São Paulo: Record, 2004. 
Artigo original

Hegemonia - Revista Eletrônica de Relações Internacionais do Centro Universitário Unieuro

ISSN: $1809-1261$

UNIEURO, Brasília, número 17, 2016, pp. 174-204.

"arapongas"18 do SNI, segundo o imaginário social.

Fico faz uma distinção entre os dois organismos originais do regime militar. A Comunidade de Informações estava sob a égide do SNI, um órgão que significativamente foi criado por lei do Executivo aprovada pelo Congresso Nacional, a 13 de junho de 1964. Inicialmente, foi imaginado para subsidiar a Presidência da República com dados relevantes para a tomada de decisões, mas, paulatinamente, foi sendo ocupado pela "linha dura" e incorporou outros poderes e funções. "Criei um monstro", diria mais tarde o general Golbery do Couto e Silva, o criador e primeiro chefe do SNI. ${ }^{19}$ Para Fico, Golbery

não integrava a linha dura, sendo conhecido por sua prosápia com fumos de intelectual, perfil que 0 identificava ao grupo da Escola Superior de Guerra, diferentemente dos militares exaltados, mais ligados às tropas e aos arroubos dos que preferiam decidir os problemas pela força. Sua preocupação com a necessidade de um órgão de informações eficaz existia havia muito tempo, remontando aos anos 1950. Para a constituição do SNI lançou mão de experiências préexistentes, como o antigo Serviço Federal de

Esse apelido pejorativo foi criado em fins dos anos 1980, com a exibição pela Rede Globo da mini-série "Araponga", na qual o ator Tarcísio Meira interpretava um agente secreto trapalhão. Caricatura de James Bond, ele repetia o bordão: "Ponga, meu nome é Araponga". 
Artigo original

Hegemonia - Revista Eletrônica de Relações Internacionais do Centro Universitário Unieuro

ISSN: $1809-1261$

UNIEURO, Brasília, número 17, 2016, pp. 174-204.

Informações e Contra-Informações (SFICI). Portanto, o SNI foi criado às claras. (...) Ao destacar a origem legal do SNI e a sua antecedência com relação ao AI-5, não quero, em absoluto, sugerir que o órgão tivesse uma origem e atuação democráticas. (...) Porém, é preciso afastar as imprecisões que foram criando em torno do SNI. ${ }^{20}$

A partir de 1968, já sob a direção do general Emílio Garrastazu Médici, o SNI passaria a dirigir as antigas Seções de Segurança Nacional, existentes desde 1946, agora transformadas nas Divisões de Segurança e Informações, as DSI, implantadas nos ministérios civis e, quase sempre, dirigidas por militares da reserva. Essas divisões trabalhavam dentro dos parâmetros de um manual militar, 0 Plano Nacional de Informações, um livro grosso, com quase mil páginas, que começou a ser elaborado pela equipe de Golbery para ensinar os membros das DSI a busca de informações para acompanhar o desenvolvimento nacional. Desta forma, a DSI do Ministério da Agricultura, por exemplo, acompanhava a produção agrícola do país, detectava os problemas climáticos e os pontos de gargalo para o escoamento da safra. Mas também investigava casos de irregularidades e de corrupção dentro da estrutura do ministério.

Todas essas informações eram passadas para o SNI. Contudo, como o órgão não dispunha, na época, de profissionais qualificados para analisar as informações sobre desenvolvimento econômico, requisitava funcionários civis dos ministérios. Já a análise política nacional e estadual - era tarefa exclusiva do SNI, geralmente elaborada por militares da ativa, requisitados das Forças Armadas. 
Artigo original

Hegemonia - Revista Eletrônica de Relações Internacionais do Centro Universitário Unieuro

ISSN: $1809-1261$

UNIEURO, Brasília, número 17, 2016, pp. 174-204.

Essa nova estrutura criada, SNI mais DSIs, formou a Comunidade Nacional de Informações, uma abrangente rede de informações para auxiliar o governo a tomar decisões. Seria o monstro ao qual Golbery mais tarde se referiu. Mas esse monstro não fazia operações de repressão política. A observação é de Carlos Fico:

Ora, Médici era muito diferente de Golbery e, na verdade, passaria à história como o homem sob cuja presidência o Brasil assistiria o auge da repressão desencadeada pela ditadura militar. Certamente, sob seu mando, o SNI mudaria. Mais do que um órgão de assessoria e de caráter informativo, o SNI transformouse em instância consultiva, capaz de vetar nomes cogitados para cargos públicos. Em julho de 1968, logo após a famosa Passeata dos Cem Mil, e diante da preocupação de Costa e Silva com a ordem pública, Médici sugeriu um instrumento assemelhado ao AI-5, que somente viria ao final do ano, sugestão recusada, na ocasião, por Costa e Silva: o SNI havia endurecido. ${ }^{21}$

E, mesmo sob a direção de Médici, ou ainda depois, sob a direção do general Carlos Alberto Fontoura, outro gaúcho que dirigiu o órgão de 1969 a 1974, do início ao fim do governo de seu amigo Médici, o SNI não participava diretamente de ações de repressão política. Fico afirma que a Comunidade de Informações

"não prendia ou torturava, sendo as Divisões de Segurança e Informações (dos ministérios) repartições públicas que se distinguiam das demais pela presença

Idem,pág. 79. 
Hegemonia - Revista Eletrônica de Relações Internacionais do Centro Universitário Unieuro

ISSN: $1809-1261$

UNIEURO, Brasília, número 17, 2016, pp. 174-204.

de militares, pelo seu ethos próprio (ânsia persecutória de base anticomunista) e pelo cuidado com as normas de sigilo. (... ) Criavam problemas para os ministros, já que obedeciam, antes de tudo, ao SNI. Mas não executavam, tarefa que cabia à polícia política, isto é, ao sistema Codi-DOI, principalmente". ${ }^{22}$

Quando teve início a guerrilha urbana no Brasil, com o Atentado de Guararapes, em 1966, mas sobretudo a partir de $1968^{23}$, o regime criou a Comunidade de Segurança, com a estruturação dos Codi-DOI (Centro de Operações de Defesa Interna - Destacamento de

Idem, ibidem.

Para a maior parte dos historiadores, o atentado à bomba no Aeroporto de Guararapes, Recife, em agosto de 1966, é apontado como marco inicial da luta armada no Brasil. O alvo o general Costa e Silva, então ministro da Guerra, mas o artefato acabou explodindo o almirante Nélson Gomez Fernandes, diretor da Companhia Energética do São Francisco, e o jornalista Édson Regis de Carvalho, além de ferir outras 17 pessoas. Luís Mir, por exemplo, em A Revolução Impossível, apresenta a ideia de que o Atentado Guararapes teria sido um evento isolado. A luta armada urbana, segundo ele, só seria sistematizada e deflagrada a partir de 1968, sob a liderança de Carlos Marighella. Em abril de 1967, Marighella, então membro do Comitê Central do Partido Comunista Brasileiro, PCB, defendeu a tese da luta armada durante a Conferência Municipal do partido em São Paulo. Venceu a cúpula, que reagiu imediatamente declarando a ilegalidade regimental da conferência. Marighella contra-atacou com ironia: "Buscam firulas jurídicas para questionar uma eleição num partido clandestino". Na sequência, em julho, Marighela partiu para uma conferência da Organização Latino-Americana Socialista em Cuba. Ali, dias após a morte de Che Guevara, fundou uma organização de luta armada, ainda sem nome, e foi ungido por Fidel estrela de primeira grandeza da revolução no continente, sucessor do mitológico guerrilheiro argentino. Nesse ínterim, o Comitê Central do PCB o expulsou do partido. Quando retornou ao Brasil, em março de 1968, definiu o nome de sua organização, Aliança Libertadora Nacional, ALN, que viria a ser o mais atuante dentre todos os grupos da luta armada urbana. Marighella morreu em 4 de novembro de 1969, numa emboscada das forças de repressão, em São Paulo. Ver detalhes em Luís Mir. A Revolução Impossível - A esquerda e a luta armada no Brasil. São Paulo: Best Seller / Círculo do Livro, 1994, págs. 244-303. 
Artigo original

Hegemonia - Revista Eletrônica de Relações Internacionais do Centro Universitário Unieuro

ISSN: $1809-1261$

UNIEURO, Brasília, número 17, 2016, pp. 174-204.

Operações de Informações) ${ }^{24}$ que, por sua vez, estavam integrados aos três centros de inteligência militares, o Centro de Informações do Exército (CIE), o Centro de Informações de Segurança da Aeronáutica (CISA) e o Centro de Informações da Marinha (CENIMAR).

Fico ressalta, ainda, que os militares só teriam estruturado e institucionalizado a Comunidade de Segurança quando foram surpreendidos pelo início da luta armada nas cidades. Ou seja, "a efetivação de antiga aspiração da esquerda pelo confronto direto com o governo tendo em vista a tomada do poder pela força" ${ }^{25}$. A função essencial desse segundo sistema era o de operar como polícia política do regime militar. Foi esse segundo sistema, formado pelos DOI-Codi e pelos três centros de inteligência militar, que prendia "subversivos", os torturava e, muitas vezes, tomava as providências necessárias para que "desaparecessem".

De qualquer forma, a partir de 1968 estava criado todo um grande sistema de segurança e informações, com duas comunidades com funções claramente distintas, a de Informações e a de Segurança. Seus integrantes eram sempre militares com cursos de aperfeiçoamento na área de Inteligência. A maioria foi treinada no

O Codi-DOI, forma usada por Fico, ou DOI-Codi, forma mais sonora e comum adotada tanto por militares como por civis, sobretudo, por militantes de esquerda, foi criado em setembro de 1970, por ordem do presidente Médici, e implementado em Brasília, São Paulo, Rio de Janeiro, Recife, Salvador, Belo Horizonte, Porto Alegre, Fortaleza e Belém. Doravante, farei uso da grafia mais conhecida, DOICodi. In: Carlos Fico, Op. Cit., págs. 79 e 80. 
Artigo original

Hegemonia - Revista Eletrônica de Relações Internacionais do Centro Universitário Unieuro

ISSN: $1809-1261$

UNIEURO, Brasília, número 17, 2016, pp. 174-204.

Centro de Estudos de Pessoal do Exército, no Forte do Leme, Rio de Janeiro. Um grupo significativo também recebeu treinamento na Escola das Américas, localizada no Panamá, dentro do território sob controle militar dos Estados Unidos.

Quase todos se conheciam e revezavam-se nos diferentes cargos e funções. Ora serviam no CIE, ora eram transferidos para o SNI, por vezes estavam na Polícia Federal, e muitas vezes, quando iam para a reserva, conseguiam um novo emprego em alguma DSI de ministério civil. Por essa razão, no imaginário deles próprios, eram todos membros daquilo que começaram a chamar de Comunidade de Informações, "homens de Informações", "especialistas em Informações". Detalhe: com o termo "Informações" sempre grafado com letras maiúsculas, tal qual os militares grafam, com maiúsculas, as armas de Infantaria, Artilharia ou Cavalaria, por exemplo.

Mais do que afinidades pessoais, eles tinham uma ideologia comum (o anticomunismo empedernido) e tinham uma causa oficial (o combate aos subversivos). Assim, os membros dessas duas comunidades, de Informações e de Segurança, que para eles próprios eram uma só, trabalhavam em sinergia e tinham uma função comum na estruturação da ditadura militar.

É necessário esclarecer que o trabalho prioritário dos órgãos de segurança militares era combater os chamados "movimentos subversivos", que ameaçavam o regime com a luta armada. A repressão política continuou sendo feita pela Polícia Federal, que na época tinha (e continua tendo) um órgão especializado, o velho DOPS criado pela ditadura Vargas. De qualquer forma, todos eles, Comunidade de Informações, Comunidade de Segurança e polícia política compartilhavam da mesma ideologia baseada na ideia da Segurança Nacional. Assim, às Forças Armadas - por Razões de Estado, segundo o conceito maquiavélico ${ }^{26}$ - foram atribuídos poderes

Em Comentários Sobre a Primeira Década de Tito Lívio, no Livro Terceiro, Capítulo Sexto, "As Conspirações", Maquiavel apresenta os contornos gerais do conceito, mas não chega a utilizar a expressão "Razões de Estado". In: Nicolau Maquiavel. Comentários Sobre a Primeira Década de Tito 
Artigo original

Hegemonia - Revista Eletrônica de Relações Internacionais do Centro Universitário Unieuro

ISSN: $1809-1261$

UNIEURO, Brasília, número 17, 2016, pp. 174-204.

de vida e de morte sobre aqueles que constituíam ameaça à ordem estabelecida.

Se o regime militar era incensado pelas Forças Armadas como um todo, se a repressão aos "terroristas" e aos "subversivos" era igualmente aplaudida nos quartéis, há de se ressalvar que os excessos cometidos pela Comunidade de Informações (ou apenas pela de Segurança, para usar a terminologia de Fico) - notadamente a tortura e as execuções sumárias - sofriam uma forte, mas silenciosa reprovação por parte das tropas regulares. Novamente Fico explica:

Diferentemente de outros pilares básicos da repressão, como a espionagem ou a censura, a tortura envergonhava, comprometia a honra de todos os militares, até mesmo porque era a primeira vez que a corporação se envolvia, diretamente, com a violência policial. ${ }^{27}$

Tal ressalva é essencial para melhor compreensão dos conflitos internos entre as tropas regulares e a Comunidade de Informações que ocorreram o tempo inteiro. No caso da repressão à guerrilha

Lívio. $2^{\mathrm{a}}$ ed. Brasília: Editora UnB, 1979, págs 314-328. A expressão apareceu pela primeira vez na obra do pensador renascentista Giovanni Botero, Della Ragion di Stato, de 1589, na qual ele, apesar de criticar a obra de Maquiavel, acaba ajudando a imortalizar o maquiavelismo vulgar contido na máxima "os fins justificam os meios". In: Nicola Abbagnano. Dicionário de Filosofia. São Paulo: Martins Fontes, 1998, verbete "Razões de Estado", pág. 830. 
Hegemonia - Revista Eletrônica de Relações Internacionais do Centro Universitário Unieuro

ISSN: $1809-1261$

UNIEURO, Brasília, número 17, 2016, pp. 174-204.

rural no Araguaia, esses conflitos foram de tal forma explícitos, que chegaram a ser registrados em documentos oficiais das Forças Armadas. Esse tema é tratado em pormenores no livro A Lei da Selva ${ }^{28}$, de minha autoria.

É trágico o saldo do fratricídio brasileiro. Entre 31 de março de 1964 e 15 março de 1985, quando tomou posse um governo civil, contabiliza-se o total de 480 mortos e desaparecidos, nos dois lados da luta. Do lado dos guerrilheiros, tanto da guerrilha urbana quanto da rural, vítimas da repressão das forças oficiais, são 381 mortos ou desaparecidos, incluindo as vítimas cuja morte ainda gera polêmica, como a estilista Zuzu Angel, símbolo da resistência civil não-marxista à ditadura militar ${ }^{29}$. Entre baixas militares e vítimas civis, são no máximo 99 pessoas, mortos em decorrência das ações guerrilheiras ${ }^{30}$.

A título elucidativo, segue trecho da referida obra: "Para os comandantes das tropas regulares, havia, na época, muita petulância dos membros da Comunidade de Informações. O termo 'petulância', aliás, foi utilizado por um antigo membro do CIE, como autocrítica, em depoimento oral para esta pesquisa. Como os agentes de inteligência eram subordinados diretamente ao ministro, estavam fora da cadeia hierárquica e tinham a liberdade de atuar em todo o País. Por isso os oficiais do CIE costumavam tentar dar ordens para a tropa regular. O coronel Pitta decidiu resistir e se recusou a fazer acordo para entregar o comando da operação ao CIE. A jurisdição sobre a área era da $8^{a}$ Região Militar. Portanto, ele conduziria aquela guerra do jeito que conhecia, segundo o manual, de acordo com a Convenção de Genebra. Mas os agentes do CIE permaneciam na área. In: Hugo Studart. A Lei da Selva - Estratégias, Imaginário e Discurso dos Militares sobre a Guerrilha do Araguaia. São Paulo: Geração, 2006, pág. 112.

Estilista de sucesso em Nova York na década de 1970, Zuleika "Zuzu" Angel promoveu uma comovente campanha internacional denunciando a tortura no Brasil. Seu filho, o universitário Stuart Angel Jones, de pai norte-americano e dupla cidadania, militante do MR-8, teria morrido nas dependências da Base Aérea do Galeão, RJ, em 14/06/71, sob tortura. Zuzu levou o caso ao senador Edward Kennedy, que denunciou o governo brasileiro no Congresso dos EUA. Conseguiu entrevista com o secretário de Estado Henrv Kissinger. Apresentou desfile de moda com motivos bélicos, "a primeira coleção de moda política do mundo", definiu. "Eu não tenho coragem, coragem tinha meu filho, eu tenho legitimidade", dizia. Sua luta para encontrar o corpo do filho comoveu a imprensa internacional. Zuzu, por sua vez, faleceu em 14/04/76, em acidente de carro no Rio de Janeiro, depois de ser fechada por outro automóvel não identificado. Especula-se que o acidente tenha sido obra dos órgãos de repressão. Ainda não foi encontrada provas concretas de assassinatos. Fonte: site Desaparecidos Políticos. . 
Artigo original

Hegemonia - Revista Eletrônica de Relações Internacionais do Centro Universitário Unieuro

ISSN: $1809-1261$

UNIEURO, Brasília, número 17, 2016, pp. 174-204.

Nos porões da ditadura

O Exército brasileiro jamais foi monolítico. $O$ general e historiador Nelson Werneck Sodré fez uma pesquisa salutar mostrando que a maior parte das organizações da esquerda brasileira, a começar pelo PCB, nasceu das costelas das Forças Armadas. $O$ próprio general Werneck Sodré nunca escondeu ser militante comunista. Mesmo depois de 1964, havia importantes núcleos comunistas dentro das Forças Armadas. E oficiais dispostos a contestar o macartismo daqueles tempos de Guerra Fria, dispostos até mesmo a se rebelar e pegar em armas, como fez o capitão Carlos Lamarca e seu grupo de sargentos que criou a VPR.

A esmagadora maioria dos militares, adestrados nos mais rígidos padrões morais positivistas e na ética cristã, professava (e ainda professa) ideias políticas tendendo ao liberalismo político e econômico, democracia representativa e capitalismo, enfim. Não eram da extrema direita hidrófoba que viam o perigo comunista em qualquer esquina, como muitos podem pensar.

Ora, se eram liberais e democratas, por que cargas d'água criaram um regime de exceção tão violento? Será que um punhado de "subversivos", "terroristas", "bandidos", "bandoleiros" - ou 
Artigo original

Hegemonia - Revista Eletrônica de Relações Internacionais do Centro Universitário Unieuro

ISSN: $1809-1261$

UNIEURO, Brasília, número 17, 2016, pp. 174-204.

qualquer outro adjetivo que os militares costumavam lhes dar representava tamanho ultraje para o estado constituído? Ora, ora, os militares eram em sua esmagadora maioria anticomunistas. Mas não eram hidrófobos diante de um gauche. Tampouco eram torturadores. Apenas preferiam o lado da democracia capitalista ocidental, liderado pelos Estados Unidos. Por conseguinte, rejeitavam com convicção o bloco liderado pela União Soviética.

Mas o fato é que entre 1964 e 1968 diferentes correntes ideológicas travavam uma forte luta interna dentro das Forças Armadas. Castello Branco, como já dito, era dos mais liberais. Contudo, o grupo mais anticomunista foi vencendo, com uma providencial ajuda da esquerda armada.

Quando o AI-5 foi baixado, em dezembro de 1968, instaurando tecnicamente um regime que a Ciência Política define por "autocrático" e a língua popular por "ditadura militar", os grupos da esquerda armada já haviam matado sete pessoas. A partir daí, tanto a maioria liberal das Forças Armadas, quanto a minoria de esquerda foi sufocada. Com o AI-5, a facção anticomunista foi oficialmente organizada e ganhou carta-branca para extirpar a ameaça terrorista.

A cada justiçamento em nome da revolução do proletariado, a cada roubo de banco para levantar fundos, a cada sequestro de diplomata estrangeiro para libertar presos políticos, a facção anticomunista recrutava mais agentes para combater o terrorismo. A cada ação da esquerda, a Comunidade de Informações ganhava mais autonomia operacional.

O Estado brasileiro, militares e civis, poderia ter vencido os adversários com os mesmos procedimentos do governo democrático da Alemanha Ocidental no combate àqueles terroristas fanáticos e ensandecidos da Baader-Meinhoff. Com polícia diligente e Judiciário eficiente. As Brigadas Vermelhas italianas, bem maiores e disseminadas do que qualquer organização da esquerda brasileira, foram igualmente derrotadas pelos governos do Partido DemocrataCristão com as melhores armas da legalidade. Nesses dois casos, 
Artigo original

Hegemonia - Revista Eletrônica de Relações Internacionais do Centro Universitário Unieuro

ISSN: $1809-1261$

UNIEURO, Brasília, número 17, 2016, pp. 174-204.

Alemanha e Itália, não há qualquer denúncia de violação dos Direitos Humanos contra seus "terroristas".

Mas governo militar, desde o AI-5 tecnicamente uma autocracia, optou pela guerra suja. Essa expressão, "guerra suja", são os próprios militares daquela época que a utilizam ainda hoje. Primeiro os comandantes militares convocaram os serviços de Inteligência das três Formas Armadas, CIE (Exército), CISA (Aeronáutica) e CENIMAR (Marinha) para participar da repressão política interna. Até aí, tudo bem, não é o certo, mas admitamos que, dentro de uma situação de exceção, por enquanto, tudo bem. Mas, o que a historiografia busca entender, ainda hoje, é como nossas Forças Armadas deixaram prevalecer práticas de exceção deploráveis, como prisões ilegais, tortura e execuções de prisioneiros.

Defendo a hipótese de que isso aconteceu quando reorganizaram o DOPS (a velha polícia política remanescente da ditadura de Getúlio Vargas) e criaram os DOI-Codi para ajudar os militares. Aqueles departamentos também precisariam de reforços. Poderiam ter recrutado quaisquer dos melhores homens da polícia civil brasileira. Em São Paulo e no Rio de Janeiro, as principais frentes de combate, optaram por membros de grupos paramilitares, os Esquadrões da Morte, um cancro que deveria ser extinto, jamais incentivado. O delegado Sérgio Fleury era o mais conhecido - e prestigiado - desses matadores.

O fato é que logo após recrutarem os Esquadrões da Morte para o trabalho de repressão política, a tortura começou. O método era tão velho quanto dominado. No pós-guerra, fora largamente utilizado pela contrainteligência militar da França nas guerras coloniais da Indochina e da Argélia, na qual prisões arbitrárias, torturas, assassinatos e terrorismo de Estado eram a regra, não a exceção. 0 método também era disseminado no bloco soviético, entre países árabes e nas ditaduras da África, as de direita e as de esquerda. A Turquia era detentora da melhor tecnologia de então. 
Artigo original

Hegemonia - Revista Eletrônica de Relações Internacionais do Centro Universitário Unieuro

ISSN: $1809-1261$

UNIEURO, Brasília, número 17, 2016, pp. 174-204.

Em pouco tempo, os militares escalados por seus pares para o trabalho de livrar o país da "ameaça terrorista", começariam a institucionalizar o Estado de exceção. Era um trabalho "sujo", portanto oculto. Foi assim que surgiu uma nova facção dentro das Forças Armadas, a autodenominada de "Comunidade de Informações", espécie de irmandade secreta.

Na maior parte do Brasil, os militares, como regra, procuravam exercer a repressão política com alguma inteligência, com conversa, até mesmo com tentativas de conversão dos jovens menos recalcitrantes à democracia capitalista ocidental. A tortura era usada, mas em casos extremos, como medida de exceção. Principalmente no início do combate à guerrilha urbana, quando acreditavam que precisariam arrancar dos prisioneiros, em menos de 48 horas, o local do próximo encontro com os companheiros.

No Rio de Janeiro e em São Paulo, contudo, justamente nos principais focos guerrilheiros, imperava a mais completa selvageria. Os quartéis da Polícia do Exército (PE) na rua Tutóia, Paraíso, e na rua Barão de Mesquita, perto do Maracanã, viraram duas sucursais do Inferno. Hegel apresentou a ideia de que todos os seres, lugares e instituições teriam um "espírito". Napoleão, por exemplo, encarnava "o espírito do mundo a cavalo". Em nosso caso em questão, foi como se o "espírito" dos Esquadrões da Morte tivessem tomado conta da alma do Exército, justo nosso Exército, que aboliu a escravidão, proclamou a República e liderou ao longo do século XX as principais lutas pelo desenvolvimento nacional.

Nessas duas sucursais do Inferno, principalmente nesses endereços, militares e policiais eram estimulados a usar o método oficial de extrair informações por quaisquer meios violentos. Logo passaram a torturar primeiro e perguntar depois. Sob a complacência boçal dos garbosos generais, o delegado Fleury chegou a arrancar os olhos de um militante que se recusava a delatar os companheiros. Ele é o mais conhecido dos torturadores, pois fazia questão de propagar suas façanhas. Contava com uma eficiente equipe sempre a postos, 
Artigo original

Hegemonia - Revista Eletrônica de Relações Internacionais do Centro Universitário Unieuro

ISSN: $1809-1261$

UNIEURO, Brasília, número 17, 2016, pp. 174-204.

estava sob as ordens e a proteção direta do delegado Romeu Tuma. Acabou chantageando os generais e restou morto, em queima de arquivo.

Entretanto, Fleury era apenas mais um entre tantos torturadores, incluindo oficiais superiores do Exército. Nem era, por sinal, o mais desumano. A grande tragédia da tortura é que ela corrói a alma não só da vítima mas também do algoz. A técnica faz despertar no torturador monstros interiores até então adormecidos. Muitos se tornaram sádicos.

"Se Deus não existe, então tudo é permitido", filosofa Fiodor Dostoiévski, em Os Irmãos Karamazov. Se Deus não existe, se não há regras éticas e morais, se os fins justificam os meios, então tudo pode. Desta forma, qual a Gestapo de Hitler ou a KGB de Stalin, tão estudadas por Arendt em Origens do Totalitarismo, nossa Comunidade de Informações acabou formando um Estado dentro do Estado. No caso, um Estado autônomo e totalitário. Virou uma irmandade, como já dito, uma organização secreta paralela que tudo via e tudo podia, repetindo aqui o velho fenômeno político do criptogoverno, estudado por Norberto Bobbio. Um monstro onividente.

Assim, com alguma inteligência (uso a expressão na acepção tradicional de serviços de espionagem e contraespionagem), mas com muitos excessos e enorme autonomia, foram derrotando as organizações de esquerda, uma a uma. A ALN, de Marighella, fora quase toda enterrada ainda em 1969. A VPR, de Carlos Lamarca, fora abatida em 1971. No início de 1972, quando descobriram um foco de guerrilha rural na região do Araguaia, todas as demais organizações urbanas estavam destroçadas, com seus líderes e principais militantes mortos, presos ou exilados. A Guerrilha do Araguaia findou, em outubro de 1974, com a prisão e execução da última guerrilheira, Walquíria Afonso Costa. Com o PC do B também derrotado, terminara toda e qualquer oposição armada ao regime militar. 
Artigo original

Hegemonia - Revista Eletrônica de Relações Internacionais do Centro Universitário Unieuro

ISSN: $1809-1261$

UNIEURO, Brasília, número 17, 2016, pp. 174-204.

O conceito de heteronomia

No clássico Raízes do Brasil, ao explicar a "Nossa Revolução"31, - mestre Sérgio Buarque de Holanda lembra que o Exército foi constituído dentro do ideário de usar a violência como defesa, jamais como arma de ataque ou conquista. Ainda no Império, explica ele, quando o Exército foi constituído para lutar na Guerra do Paraguai, o Estado queria impor-se apenas pela grandeza da imagem que criara de si e recorreu à guerra para se fazer respeitar, não por ambição de conquista. "Se Ihe sobrava, por vezes, certo espírito combativo, faltava-Ihe espírito militar 32". Sérgio cita Oliveira Lima, para quem "as guerras estrangeiras, como métodos políticos, sempre foram encaradas pelo país como importunas e até criminosas, e nesse sentido especialmente a Guerra do Paraguai não deixou de sê-lo; os voluntários que a ela acudiram, eram, muito pouco por vontade própria" ${ }^{33}$. Sérgio Buarque de Holanda ainda argumenta:

O capítulo VII, o último, se chama "Nossa Revolução". Quando escreveu sobre o tema, em 1936, Sérgio estava se referindo "ao processo geral - e em verdade revolucionário - da transformação dos territórios coloniais em sociedades cultas e modernas". Para ele, o termo "revolução" não tinha, necessariamente, a acepção de convulsão ou sangue. Contudo, esclareço que venho utilizando a expressão "nossa revolução" ao longo desta pesquisa para me referir às experiências de luta armada que povoaram o imaginário dos militares brasileiros no período da Guerra Fria. In: Sérgio Buarque de Holanda. Raízes do Brasil. São Paulo: Companhia das Letras, $26^{a}$ ed. 1995, pág. 126.

Idem, ibidem, pág. 176.

APUD: Holanda, op. cit., pág 176. Oliveira Lima. Aspectos da História e da Cultura do Brasil. Lisboa, 1923, pág. 78. 
Artigo original

Hegemonia - Revista Eletrônica de Relações Internacionais do Centro Universitário Unieuro

ISSN: $1809-1261$

UNIEURO, Brasília, número 17, 2016, pp. 174-204.

Não ambicionamos o prestígio de país conquistador e detestamos notoriamente as soluções violentas. Desejamos ser o povo mais brando e mais comportado do mundo. Pugnamos constantemente pelos princípios tidos universalmente como os mais moderados e racionais. ${ }^{34}$

Quando eclodiu a luta armada no Brasil, urbana e rural, todo imaginário militar brasileiro era baseado - e ainda é - nos princípios da "defesa da paz" e da "soberania nacional", ideias estas incluídas no próprio refrão do Hino do Soldado, cantado diariamente nos quartéis: "A paz queremos com fervor/ Guerra só nos causa dor/ Porém se a pátria amada/ for um dia ultrajada/ lutaremos com fervor"

O conceito do imaginário tem como preocupação superar a dicotomia entre a verdade e a mentira, entre o certo e o errado, entre o Bem e o Mal. Para o filófoso Cornelius Castoriadis, os valores integram o imaginário social que norteia o comportamento humano ${ }^{35}$. Nesse sentido, os militares que combateram as organizações de vanguarda agiam norteados por valores que estavam inseridos em sua própria época. Assim, o que mais chama a atenção sobre a atuação dos militares naquele episódio, é a forma como esses valores

Op. cit., pág. 176.

Cornelius Castoriadis. A instituição imaginária da sociedade. Op. cit, pág. 162. 
Artigo original

Hegemonia - Revista Eletrônica de Relações Internacionais do Centro Universitário Unieuro

ISSN: $1809-1261$

UNIEURO, Brasília, número 17, 2016, pp. 174-204.

tradicionais dos militares foram totalmente perdidos a partir de determinado momento.

Michael Maffesoli ${ }^{36}$ apresenta o conceito da suspensão de valores. Ele encontra inspiração no pensamento de Durkheim ${ }^{37}$, autor original do conceito de que a sociedade seria algo que transcende 0 indivíduo, que é formada por ideias, por um mínimo de consenso que gera coesão social e unidade ficcional, mesmo com as imperfeições da pulsão dos desejos egressos da diversidade.

O eixo fundamental do pensamento de Maffesoli é a ideia do tempo presente, o que ele denomina "presenteísmo": livra-se do presente quando se vive em contraposição com o passado ou com o futuro, ou seja, quando se vive o sonho, a utopia, a ideologia. É o instinto de conservação de um determinado sujeito social, explica Maffesoli, que provoca a sinergia coletiva, aquilo que ele chama de "potência voltada para a agressividade", geradora dos conflitos sociais e das revoluções. É essa potência popular que marca o ritmo da mudança, que desencadeia revoluções violentas e lutas extremistas, como aquela ocorrida no Brasil.

Desse modo, sobre a atuação dos militares na repressão às guerrilhas urbana e rural, o que mais chama a atenção é a forma como alguns valores foram totalmente perdidos a partir de

Michel Maffesoli. A Conquista do Presente. Trad. Márcia de Sá Cavalcante. Rio de Janeiro: Rocco, 1984.

David Emile Durkheim, é considerado o fundador da Sociologia como ciência independente. Estudou o suicídio, o qual, segundo ele, seria praticado na maioria das vezes por causa da desilusão do indivíduo com o seu meio social. 
Artigo original

Hegemonia - Revista Eletrônica de Relações Internacionais do Centro Universitário Unieuro

ISSN: $1809-1261$

UNIEURO, Brasília, número 17, 2016, pp. 174-204.

determinado momento. Trabalho com a hipótese de que, durante a repressão militar à luta armada, tenha havido uma "pulsão dos desejos", de encontrar a sinergia coletiva por meio da violência radical. ${ }^{38} \mathrm{Em}$ consequência, teria ocorrido uma suspensão dos valores, segundo o conceito de Maffesoli.

O conceito da suspensão de valores diagnostica a doença, a consequência. Contudo, não aponta a causa. Em outras palavras, e insistindo na questão, o que teria levado nossos militares a suspender seus valores tradicionais e começar a torturar, matar, desaparecer com os corpos dos adversários políticos, enfim, a cometer toda sorte de atos de exceção?

As respostas para tais reflexões podem ser encontradas no conceito de heteronomia, apresentado inicialmente por Hannah Arendt e, mais tarde, aprofundado por Castoriadis. A heteronomia deve ser entendida como a condição de pessoa ou de grupo que receba de um elemento que lhe é exterior, ou de um princípio estranho à razão, a lei a que se deve submeter ${ }^{39}$.

Embora o corpo principal do trabalho de Arendt sobre totalitarismo seja anterior aos estudos sobre o imaginário, ela em muito ajudou a pavimentar as análises de Castoriadis sobre a heteronomia. Arendt começou aceitando a dicotomia na interpretação histórica e fazendo uso dos conceitos do Bem e do Mal, mas acabou

O termo "radical" está aqui empregado na acepção de Hannah Arendt, sinônimo de extremismo. Castoriadis prefere utilizar o termo "radicalismo", guardando "radical" como significado de raiz, gênese.

Aurélio Buarque de Holanda. Novo Dicionário da Língua Portuguesa. Rio de Janeiro: Nova Fronteira, $1^{\text {a }}$ Ed., $10^{\mathrm{a}}$ impressão, 1985, pág. 721. 
Artigo original

Hegemonia - Revista Eletrônica de Relações Internacionais do Centro Universitário Unieuro

ISSN: $1809-1261$

UNIEURO, Brasília, número 17, 2016, pp. 174-204.

por rejeitar o maniqueísmo e concluiu que o melhor caminho seria o do conceito da heteronomia.

Quando escreveu Origens do Totalitarismo ${ }^{40}$, ao final da Segunda Guerra, Arendt ousou traçar um paralelo entre o nazismo e o stalinismo, considerando que ambos seriam muito semelhantes por conta das práticas totalitárias. Alemã e judia, dedicou-se muito mais a estudar a ascensão de Hitler, mas também arranhou com bastante eficiência a imagem do grupo político que tomou de assalto o estado soviético em nome da utopia igualitarista. Traçar comparações e paralelos entre os dois regimes foi considerado atitude espúria pela esquerda na ocasião.

Naquela época, a União Soviética e Joseph Stalin ainda eram tratados com fervor quase religioso pelos seguidores do socialismo. Os marxistas argumentavam que o termo "totalitário" seria inscrito no contexto de guerra fria e que seu uso seria uma tática do capitalismo liberal para tentar desmoralizar o socialismo real e a ditadura do proletariado. Mais tarde, na década de 1970, pensadores do quilate de Giovani Sartori e Raymond Aron chegaram a decretar o totalitarismo como um acidente histórico já superado. Os acontecimentos posteriores, como o nacionalismo balcânico e o fundamentalismo islâmico, comprovaram ser essa corrente excessivamente otimista.

Arendt começou a se interessar pelo tema ao fim da Segunda Grande Guerra, chocada que estava com os acontecimentos políticos da época, sobretudo com os horrores do holocausto. Tentava encontrar explicações filosóficas para compreender o fenômeno totalitário. Naquela ocasião, encontrou em Kant o conceito de Mal Radical. Mais tarde, em 1963, quando foi contratada pela revista The New Yorker para relatar o julgamento de Adolf Eichmann, em Jerusalém, elaborou suas reflexões acerca do fenômeno da violência 
Artigo original

Hegemonia - Revista Eletrônica de Relações Internacionais do Centro Universitário Unieuro

ISSN: $1809-1261$

UNIEURO, Brasília, número 17, 2016, pp. 174-204.

e do totalitarismo.

Ao chegar em Jerusalém para o julgamento de Eichmann, ela esperava encontrar, no mínimo, um homem perverso, um monstro, um exemplar de malignidade humana, como fazia acreditar a imprensa na época. Hannah Arendt, contudo, ficou surpresa ao encontrar um homem comum, que podia ser caracterizado como tendo apenas um "vazio de pensamento".

Concluiu que o acusado não seria um monstro, mas "um homem com extremo grau de heteronomia"; ou seja, segundo a pensadora, Eichmann não passava de um pacato servidor público disposto a não pensar, a não elaborar, disposto somente a cumprir ordens, a qualquer preço, custe o que custar. Enfim, um indivíduo que era um produto típico do estado totalitário.

Foi, então, que Arendt passou a encarar o problema do Mal dentro da sua dimensão política, numa visão original, que é a dimensão da banalidade, da falta de grandeza. Ainda, de acordo com sua visão, as instituições públicas dos regimes totalitários dariam aos seus agentes o sentimento de embriaguez, de servir as forças superiores e aos vastos desígnios nos quais eles não são eles mesmos, mas apenas instrumentos tão dóceis como irresponsáveis. Em outras palavras, simples agentes cumprindo à risca a política do Estado. Foi essa "política infantil" que teria levado os arianos "eleitos" a produzir massacres administrativos em Treblinka e Sobidor, por exemplo, explica a pensadora. Esse fenômeno é definido como heteronomia.

Castoriadis introduziu a questão da heteronomia especificamente dentro dos estudos do imaginário. Para o filósofo, o fenômeno ocorre quando

o sujeito não se diz, mas é dito por alguém, existe pois como parte do mundo de um outro (certamente, por sua vez, travestido). O sujeito é dominado por um imaginário vivido como mais real que o real, ainda que não sabido como tal. 0 essencial da heteronomia - ou da alienação, no 
Artigo original

Hegemonia - Revista Eletrônica de Relações Internacionais do Centro Universitário Unieuro

ISSN: $1809-1261$

UNIEURO, Brasília, número 17, 2016, pp. 174-204.

sentido amplo do termo - no nível individual, é o domínio por um imaginário autonomizado que se arrojou a função de definir para o sujeito tanto a realidade quanto seu desejo.

A questão do imaginário aparece na obra de Castoriadis no contexto de uma discussão sobre instituições, alienação e autonomia. Esses três conceitos são importantes para a análise do imaginário em eventos históricos relacionados a questões ideológicas e, em última instância, a revoluções. O imaginário, segundo o autor, é uma invenção, uma criação de sentidos. O imaginário não é a imagem de algo; não é só a representação do real, a mnese, mas é todo ele invenção, criação, vem da ordem da psique, mas que deve ter verossimilhança com o real, para que seja crível. O conceito de imaginário é utilizado com o intuito de acabar com dicotomias, maniqueísmos e afins. Para Castoriadis,

A humanidade teve e tem fome de alimento, mas ela também teve fome de vestimentas e em seguida de outras vestimentas que não as do ano anterior, ela teve fome de automóveis e de televisão, fome de poder e fome de santidade, ela teve fome de ascetismo e de libertinagem, ela teve fome de místico e fome de saber racional, teve fome de amor e de fraternidade, mas também fome de seus próprios cadáveres e, agora, parece que começa a ter fome da Lua e de planetas. É preciso uma boa dose de cretinismo para pretender que ela inventou todas essas fomes porque não conseguia comer ou fazer amor suficientemente.( grifo meu)

O conceito tradicional de instituição toma por base os valores sociais cristalizados, os valores sacramentados, que garantem a reprodução das tradições, dos valores instituídos, que sobrevivem ao 
Artigo original

Hegemonia - Revista Eletrônica de Relações Internacionais do Centro Universitário Unieuro

ISSN: $1809-1261$

UNIEURO, Brasília, número 17, 2016, pp. 174-204.

tempo e às gerações e que asseguram a sobrevivência das sociedades. Castoriadis apresenta um outro conceito para instituição, diferente do tradicional. Para ele, trata-se de uma construção e dispositivo inscrito em uma rede simbólica. Para ele, é nas instituições sociais que encontramos os significantes e os significados dos símbolos e dos valores reconhecidos pela sociedade. O papel da instituição, segundo Castoriadis, está cravado no histórico social, ou seja, os sujeitos estão no mundo numa relação com as instituições, pois as instituições são criações humanas, enredados em sua rede simbólica.

Encontramos primeiro o simbólico, é claro, na linguagem. Mas o encontramos igualmente, num outro grau e de uma outra maneira, nas instituições. As instituições não se reduzem ao simbólico, mas elas só podem existir no simbólico, são impossíveis fora de um simbólico em segundo grau e constituem cada qual sua rede simbólica.

A partir daí, Castoriadis vai construindo os conceitos de autonomia e alienação. Ele apresenta esses conceitos como uma crítica ao fenômeno da autonomização. Segundo Castoriadis, à medida que a instituição ganha força, começa a se autonomizar. No momento em que a instituição adquire a autonomização, vem consequentemente a alienação. A alienação surge como uma modalidade da relação com a instituição e, por seu intermédio, da relação com a história. Em outras palavras, a instituição começa a funcionar como se não tivesse dentro do contexto histórico, começa se deslocando da sociedade, de seus valores e do código de conduta social. A instituição autônoma se aliena e começa a agir segundo valores deslocados da conduta da sociedade na qual está inserida.

A alienação é a autonomização e a dominância do momento imaginário na instituição que propicia a autonomização e a dominância da instituição relativamente à sociedade. (...) Ou seja, a sociedade 
Artigo original

Hegemonia - Revista Eletrônica de Relações Internacionais do Centro Universitário Unieuro

ISSN: $1809-1261$

UNIEURO, Brasília, número 17, 2016, pp. 174-204.

não reconhece no imaginário das instituições seu próprio produto.

Transportando para o objeto em questão, a repressão à luta armada no Brasil, teria sido a heteronomia que levou oficiais como o coronel Carlos Alberto Brilhante Ustra, comandante do DOI-Codi em São Paulo durante o governo Médici, a transformar aquele órgão público numa sucursal do Inferno. Em seu período à frente do DOICodi, entre 1970 e 1974, teriam ocorrido 502 denúncias de tortura, de acordo com a Comissão de Justiça e Paz da Arquidiocese de São Paulo, e pelo menos 50 mortes, segundo apontou, em 2013, a Comissão Nacional da Verdade.

O brazilianist Thomas Skidmore registra em sua obra Brasil: de Castelo a Tancredo, que foi, a então deputada (e atriz), Bete Mendes quem reconheceu Ustra como seu torturador, em 1986, quando ele fora adido militar no Uruguai e integrava a lista de promoções a general. Ela então enviou uma carta ao presidente José Sarney solicitando que fosse exonerado do cargo e pronunciou um discurso na Câmara dos Deputados. Desde então, passou a encarnar o representante mais visível dos porões da ditadura, símbolo-mor do torturador.

Em resposta às primeiras acusações, Ustra lançou o livro Rompendo o Silêncio, no qual narra sua passagem pelo DOI-Codi e nega a acusação de torturado. Depois, em 2006, lança o livro A Verdade Sufocada, na qual relata a luta armada perpetrada pelas organizações de vanguarda, as quais trata por "terroristas". Em 2008, Ustra foi condenado pela Justiça de São Paulo, em primeira instância, por sequestro e tortura, mais de 30 anos depois dos fatos ocorridos. O fato é que, até a data de sua morte, em outubro de 2015, o coronel, mais um entre centenas de outros, jamais declarou qualquer tipo de autocrítica ou de arrependimento por seus atos. Ao contrário, orgulhava-se deles, tal qual Adolf Eichmann - a quem Arendt apontou como portador de um "vazio do pensamento".

Outro episódio que igualmente ilustra aquilo que Arendt chama 
Artigo original

Hegemonia - Revista Eletrônica de Relações Internacionais do Centro Universitário Unieuro

ISSN: $1809-1261$

UNIEURO, Brasília, número 17, 2016, pp. 174-204.

de "sentimento de embriaguez" de servir às instituições públicas, ocorreu durante a Guerrilha do Araguaia, na execução da guerrilheira Dinaelza Santana Coqueiro, codinome Maria Diná. Estudante de Geologia na Bahia, Maria Diná era uma das mais conhecidas guerrilheiras do Araguaia. Carregava entre os companheiros, os moradores da região e entre os militares, a imagem de valente, corajosa, perigosa. É seu próprio algoz quem relata:

Era braba pra cacete, aguentou um pau violento, uns cinco ou seis dias de pau. Aí contou a história dela. Então nossa equipe a levou. Na hora, minha pistola engasgou. Engasgou e não saiu mais bala nenhuma. Ela me olhava com um ódio danado. Não chorou, só me olhava com ódio, um ódio fantástico, ódio, muito ódio. Foi uma merda. Então eu tive que pegar outra arma. Um companheiro chegou perto e me ajudou a fazer o serviço.

O que esse agente do estado totalitário teria sentido ao encarar os olhos da vitima? Ele próprio responde:

"Eu? Com ela, nada. Eu estava preparado para fazer aquilo mesmo".

Somente o "nada", o "vazio do pensamento"? Seria o militar, tal qual o coronel Ustra, um homem perverso, um monstro, um exemplar de malignidade humana, como um dia Arendt de início imaginou que Eichmann fosse? Será que ele estaria mesmo preparado para fazer aquilo, como disse que estava?

Como bem lembrou Castoriadis, em seu intuito de utilizar os estudos do imaginário para acabar com dicotomias, maniqueísmos e afins na análise da história, a humanidade tem fome de poder e de seus próprios cadáveres, mas também tem fome de santidade, fome de místico, fome de amor e de fraternidade. E agora, ainda parafraseando Castoriadis, parece que começa a ter fome da Lua e de 
Artigo original

Hegemonia - Revista Eletrônica de Relações Internacionais do Centro Universitário Unieuro

ISSN: $1809-1261$

UNIEURO, Brasília, número 17, 2016, pp. 174-204.

planetas, fome de consciência e de sobriedade. Fome até mesmo de pedir perdão por um dia ter sido - como definiu Hannah Arendt - um agente dócil e embriagado pelo regime totalitário instaurado no Brasil depois do movimento de 1964.

Em conclusão, teria sido o fenômeno da heteronomia - propõe este ensaio - que teria levado nossos militares a instaurar um Estado autocrático que adotou como prática cotidiana da repressão a violação sistemática dos Direitos Humanos, embriagando seus agentes com o sentimento de dever cumprido.

Referências

ABBAGNANO, Nicola. Dicionário de Filosofia. São Paulo: Martins Fontes, 1998.

ARENDT, Hannah. Origens do Totalitarismo. São Paulo: Companhia das Letras, 1990.

Eichmann em Jerusalém. Brasília: Editora UnB / São Paulo:

Companhia das Letras, 2000.

CASTORIADIS, Cornelius. A Instituição Imaginária na Sociedade. Rio de Janeiro: Paz e Terra, 1982.

CÓRDOVA, Rogério de Andrade. "Imaginário Social e Educação". In: Revista "Em Aberto", Brasília, Ano 14, no 61, ed. Jan/Mar, 1994.

FERREIRA, Oliveiros S. Vida e Morte do Partido Fardado. São Paulo: Editora Senac São Paulo, 2000.

. Os 45 Cavalheiros Húngaros - Uma leitura dos Cadernos de Gramsci. Brasília: Editora Universidade de Brasília; São Paulo: Hucitec, 1986.

FICO, Carlos. Além do Golpe - Versões e controvérsias sobre 1964 e a Ditadura Militar. São Paulo: Record, 2004. 
Artigo original

Hegemonia - Revista Eletrônica de Relações Internacionais do Centro Universitário Unieuro

ISSN: $1809-1261$

UNIEURO, Brasília, número 17, 2016, pp. 174-204.

FOUCAULT, Michel. Vigiar e Punir. $18^{\mathrm{a}}$ ed., Petrópolis: Ed. Vozes, 1987.

HOLANDA, Aurélio Buarque de. Novo Dicionário da Língua Portuguesa. Rio de Janeiro: Nova Fronteira, $1^{a}$ Ed., 10 ${ }^{a}$ impressão, 1985.

HOLANDA, Sérgio Buarque de. Raízes do Brasil. São Paulo: Companhia das Letras, 26a ed., 1995.

IANNI, Octavio. Política e revolução social no Brasil". Rio de Janeiro : Civilização Brasileira, 1965.

MAFFESOLI, Michel. A Conquista do Presente. Trad. Márcia de Sá Cavalcante. Rio de Janeiro: Rocco, 1984.

MAQUIAVEL, Nicolau. Comentários Sobre a Primeira Década de Tito Lívio. 2a ed. Brasília: Editora UnB, 1979.

MIR, Luís. A Revolução Impossível - A esquerda e a luta armada no Brasil. São Paulo: Best Seller / Círculo do Livro, 1994.

SKIDMORE, Thomas. Brasil: de Castelo a Tancredo. São Paulo: Paz e Terra, 1997.

SOUKI, Nádia. Hannah Arendt e a Banalidade do Mal. Belo Horizonte: Editora UFMG, 1998.

STEPAN, Alfred. Os Militares na Política. Trad. Ítalo Tronca. Rio de Janeiro: Artenova, $1^{\text {a ed. }} 1975$.

STUDART, Hugo. A Lei da Selva - Estratégias, Imaginário e Discurso dos Militares sobre a Guerrilha do Araguaia. São Paulo: Geração, 2006.

USTRA, Carlos Alberto Brilhante. Rompendo o Silêncio. Brasília: Edição Pessoal, 1987. . A Verdade Sufocada. Brasília: Edição Pessoal, 2006.

Sítios de internet:

Desaparecidos Políticos. www.desaparecidospoliticos.org.br.

Grupo Terrorismo Nunca Mais, site www.ternuma.com.br. 